\title{
PERUMUSAN DIAGNOSA KEPERAWATAN DALAM MENCAPAI ASUHAN KEPERAWATAN
}

Natalia Cristianti P Marbun

\author{
christiantinatalia72@gmail.com
}

\section{LATAR BELAKANG}

Pelayanan keperawatan merupakan bagian integral dari pelayanan kesehatan yang bisa menjadi tolak ukur keberhasilan dalam pencapaian tujuan suatu rumah sakit. Kualitas pelayanan keperawatan berjalan dengan baik apabila proses keperawatan yang dilaksanakan terstruktur dengan baik (Farlinda, 2011). Kualitas pelayanan yang baik akan meningkatkan kepuasan pasien dan keluarga demikian juga sebaliknya jika pasien dan keluarga tidak puas maka akan meninggalkan rumah sakit bila kualitas pelayanan buruk (Muhlisin, 2008).

Keperawatan adalah suatu bentuk pelayanan profesional merupakan bagian integral dari pelayanan kesehatan bersifat komprehensif terdiri dari bio, psiko, sosial dan spiritual ditujukan kepada individu, keluarga, keluarga kelompok dan masyarakat baik sehat maupun sakit berdasarkan ilmu dan kiat. Lansia baik sebagai individu maupun kelompok merupakan sasaran dari pelayanan keperawatan.

Perawat sebagai tenaga kesehatan yang bertugas untuk memenuhi kebutuhan dasar klien secara holistic.Dalam tindakannya, seorang perawat sebelum memberikan asuhan keperawatan harus melakukan metode keperawatan berupa pengkajian, diagnosis keperawatan, intervensi, dan evaluasi. Profesi perawat menggunakan proses keperawatan (nursing process) sebagai kerangka pikir dan kerangka kerja dalam merawat pasien.

Diagnosa Keperawatan merupakan keputusan klinik tentang respon individu, keluarga dan masyarakat tentang masalah kesehatan aktual atau potensial, dimana berdasarkan pendidikan dan pengalamannya, perawat secara akuntabilitas dapat mengidentifikasi dan memberikan intervensi secara pasti untuk menjaga, menurunkan, membatasi, mencegah dan merubah status kesehatan klien (Yeni, 2008). Untuk dapat merumuskan diagnosa keperawatan dibutuhkan kemampuan analisis yang tinggi sehingga diperlukan sumber daya manusia yang capable dan mempunyai motivasi kuat untuk maju serta berpandangan maju (futuristic). Pada status pasien yang telah dikaji terlihat bahwa perawat hanya memilih saja diagnosa keperawatan yang telah disediakan di bagian samping format pengkajian. Hal ini memang lebih memudahkan perawat akan tetapi juga dapat menyebabkan perawat menjadi malas dan kurang inisiatif untuk 
menganalisa data lalu merumuskan diagnosa keperawatan sendiri apabila ditemukan data yang berbeda. Kondisi demikian juga menimbulkan kualitas pendokumentasian diagnosa keperawatan

\section{METODE}

Metode yang digunakan dalam kajian Perumusan diagnosa keperawatan dalam mencapai asuhan keperawatan ini menggunakan metode pengumpulan data dengan menggunakan literature review berdasarkan teks buku,buku referensi,jurnal (10 tahun terakhir) dengan menganalisis dan membaca setiap sumber literature berkenaan dengan topik materi yang sedang dibahas untuk mendapatkan berbagai informasi yang lengkap dan akurat dengan cara menyimpulkannya dari literature review yang ada.

\section{HASIL}

Berdasarkan hasil dari setiap literature review yang saya dapatkan,yaitu seperti buku teks,jurnal atau buku referensi lainnya bahwasanya Diagnosia keperawatan adalah " Clinical Judgment" yang berfokus pada respon manusia terhadap kondisi kesehatan atau proses kehidupan atau kerentanan (vulnerability) baik pada individu, keluarga, kelompok atau komunitas (NANDA, 2015-2017).

Diagnosa keperawatan adalah keputusan klinis mengenai seseorang, keluarga, atau masyarakat sebagai akibat dari masalah kesehatan atau proses kehidupan yang aktual atau potensial. Diagnosa keperawatan merupakan dasar dalam penyusunan rencana tindakan asuhan keperawatan.Diagnosis keperawatan sejalan dengan diagnosis medis sebab dalam mengumpulkan data-data saat melakukan pengkajian keperawatan yang dibutuhkan untuk menegakkan diagnosa keperawatan ditinjau dari keadaan penyakit dalam diagnosa medis

Diagnosa keperawatan adalah suatu bagian integral dari proses keperawatan. Hal ini merupakan suatu komponen dari langkah-langkah analisa, dimana perawat mengidentifikasi " respon-respon individu terhadap masalah-masalah kesehatan yang aktual dan potensial." Pada beberapa negara ( mis., Kansas, New york ) mendiagnosa diidentifikasikan dalam tindakan Praktik Keperawatan sebagai suatu tanggung jawab legal dari seorang perawat professional, Diagnosa keperawatan memberikan dasar petunjuk untuk memberikan terapi yang pasti dimana perawat bertanggung jawab di dalamnya. Diagnosa keperawatan, sebagai suatu bagian dari proses keperawatan juga direfleksikan dalam standar praktik ANA. Standar-standar ini memberikan satu dasar luas mengevaluasi praktik dan merefleksikan pengakuan hak-hak manusia yang menerima asuhan keperawatan .

Pada prakteknya, perawat sering mengalami kesulitan dalam melaksanakan asuhan keperawatan. Sering sekali perawat kesulitan dalam hal menetapkan diagnosa keperawatan yang tepat bagi pasien. Pada kasus yang lain, data dikumpulkan tanpa menyadari mengenai apa diagnosanya?. 
Perawat juga mengumpulkan data yang mempunyai relevansi yang rendah dengan diagnosa keperawatan tertentu. Penelitian menunjukkan bahwa rendahnya keakuratan dalam diagnosa keperawatan berkaitan dengan banyaknya jumlah data yang relevansinya rendah (Nurjannah I, 2012). Kelengkapan pengisian berkas rekam medis oleh tenaga kesehatan akan memudahkan tenaga kesehatan lain dalam memberikan tindakan atau terapi kepada pasien. Selain itu juga sebagai sumber data pada bagian rekam medis dalam pengolahan data yang kemudian akan menjadi informasi yang berguna bagi pihak manajemen dalam menentukan langkah-langkah strategis untuk pengembangan pelayanan kesehatan.

\section{PEMBAHASAN}

Diagnosa keperawatan adalah sebagai keputusan klinis mengenai individu, keluarga, atau masyarakat yang diperoleh melalui suatu proses pengumpulan data, analisis cermat dan sistematis terhadap masalah kesehatan yang aktual maupun potensial guna menjaga status kesehatan dan memberikan dasar pembuatan ketentuan+ketentuan untuk terapi yang pasti dimana perawat ambil bagian untuk bertanggung jawab akan hal itu.

1. Langkah-Langkah Penulisan Diagnosa Keperawatan

Langkah-langkah dalam penulisan diagnosa keperawatan terdiri dari:

1. Pengelompokan Data dan Analisa data

a. Data Subjektif Contoh: "Pasien mengeluhkan nyeri saat menelan karena ada tumor di leher, akibatnya $\mathrm{BB}$ turun lebih dari $10 \mathrm{~kg}$ dalam 12 bulan berakhir, karena nyeri menelan."

b. Data Objektif Contoh: $\mathrm{TB}=165 \mathrm{~cm}, \mathrm{BB}=45 \mathrm{~kg}$

\section{Interpretasi Data}

Langkah yang dilakukan dalam interpretasi data adalah :

a. Menentukan kelebihan klien

Jika pasien memenuhi standar kriteria kesehatan, bisa disimpulakan bahwa klien memiliki kelebihan dalam hal tertentu yang dapat digunakan untuk meningkatkan atau membantu memecahkan masalah yang dihadapai klien.

b. Menentukan masalah klien

Jika klien tidak memenuhi standar kriteria kesehatan, maka klien mengalami keterbatasan dalam aspek kesehatan yang memerlukan bantuan/asuhan keperawatan. 
c. Menentukan masalah klien yang pernah dialami.

Tahap ini perlu dilakukan untuk menentukan masalah klien.

3. Validasi Data

Validasi data ini dilakukan untuk memastikan ke akuratan diagnosa dimana perawat bersama pasien memvalidasi diagnosa sehingga diketahui bahwa pasien setuju dengan masalah yang sudah dibuat dan faktor-faktor yang mendukungnya. Contoh: Perawat mengukur BB pasien akibat tumor yang dideritanya.

\section{Penyusunan Diagnosa Keperawatan}

Penyusunan diagnosa keperawatan (dengan rumusan $\mathrm{P}+\mathrm{E}+\mathrm{S}$ )

$\mathrm{P}=$ Problem $\mathrm{E}=$ Etiolog $\mathrm{S}=$ Symptom. Contoh: Gangguan pemenuhan nutrisi: kurang dari kebutuhan tubuh berhubungan dengan intake yang tidak adekuat ditandai dengan klien mengatakan $\mathrm{BB}$ turun lebih dari $10 \mathrm{~kg}$ dalam 12 bulan terakhir, $\mathrm{TB}=165 \mathrm{~cm}, \mathrm{BB}=45 \mathrm{~kg}$. Dari contoh diagnosa di atas, dapat diketahui:

- Problemnya adalah: gangguan pemenuhan nutrisi kurang dari kebutuhan tubuh.

- Etiologinya adalah: intake yang tidak adekuat.

- Symptomnya adalah: klien mengatakan BB turun lebih dari $10 \mathrm{~kg}$ dalam 12 bulan terakhir, klien mengeluh nyeri saat menelan, sehinggan menghindari untuk tidak makan, $\mathrm{TB}=170 \mathrm{~cm}$, $\mathrm{BB}=50 \mathrm{~kg}$.

Keputusan yang dapat diberikan dalam masalah kesehatan klien adalah sebagai berikut :

Tidak ada masalah:

Tidak ada indikasi respon keperawatan.

Meningkatnya status kesehatan dan kebiasaan.

Adanya inisiatif promosi kesehatan untuk meningkatkan derajat kesehatan yang optimal misalnya pendidikan kesehatan pada keluarga/komunitas/individu.

Adapun persyaratan dari diagnosa keperawatan ialah, perumusan wajib jelas dan singkat dari respons klien terhadap situasi yang dihadapi, spesifik dan akurat, memberikan arahan pada askep, bisa dikerjakan oleh perawat dan mencerminkan keadaan kesehatan klien.

\section{Kategori Diagnosa Keperawatan}

Diagnosa keperawatan dapat dibedakan menjadi 5 kategori: 
1) Aktual, Aktual Diagnosa Keperawatan menjelaskan masalah nyata saat ini sesuai dengan data klinik yang ditemukan. Diagnosis berfokus pada masalah (diagnosis aktual) adalah clinical judgment yang menggambarkan respon yang tidak diinginkan klien terhadap kondisi kesehatan atau proses kehidupan baik pada individu, keluarga, kelompok dan komunitas. Hal ini didukung oleh batasan karakteristik kelompok data yang saling berhubungan. Contoh : 1) Ketidakseimbangan nutrisi: kurang dari kebutuhan tubuh, 2) gangguan pola nafas, 3) gangguan pola tidur, 4) disfungsi proses keluarga, 5) ketidakefektifan manajemen regimen terapeutik keluarga. Syarat menegakkan diagnosa keperawatan aktual harus ada unsur PES.Symptom (S) harus memenuhi kriteria mayor dan sebagian kriteria minor dari pedoman diagnose. Diagnosia keperawatan mempunyai empat komponen : label, definisi, batasan karakteristik, dan faktor yang berhubungan.

2) Resiko, Risiko Diagnosa Keperawatan menjelaskan masalah kesehatan yang nyata akan terjadi jika tidak dilakukan intervensi. Syarat menegakkan risiko diagnosa keperawatan adanya unsur PE (problem dan etiologi).Penggunaan istilah "risiko dan risiko tinggi" tergantung dari tingkat keparahan/kerentanan terhadap masalah. Diagnosa: "Risiko gangguan integritas kulit berhubungan dengan diare yang terus menerus"

3) Kemungkinan, Kemungkinan Diagnosa Keperawatan menjelaskan bahwa perlu adanya data tambahan untuk memastikan masalah keperawatan kemungkinan.Pada keadaan ini masalah dan faktor pendukung belum ada tapi sudah ada faktor yang dapat menimbulkan masalah.Syarat menegakkan kemungkinan diagnosa keperawatan adanya unsur respons (Problem) dan faktor yang mungkin dapat menimbulkan masalah tetapi belum ada. Contoh: Diagnosa: Kemungkinan gangguan konsep diri: rendah diri/terisolasi berhubungan dengan diare. Perawat dituntut untuk berfikir lebih kritis dan mengumpulkan data tambahan yang berhubungan dengan konsep diri

4) Keperawatan wellness, Diagnosa keperawatan wellness (sejahtera) adalah keputusan klinik tentang keadaan individu, keluarga, dan atau masyarakat dalam transisi dari tingkat sejahtera tertentu ke tingkat sejahtera yang lebih tinggi. Ada 2 kunci yang harus ada: 1) Sesuatu yang menyenangkan pada tingkat kesejahteraan yang lebih tinggi 2) Adanya status dan fungsi yang efektif.

5) Keperawatan Sindrom. Diagnosis keperawatan sindrom adalah clinical judgement yang menggambarkan suatu kelompok diagnosis keperawatan yang terjadi bersama, mengatasi masalah secara bersama dan melalui intervensi yang sama. Sebagai contoh adalah sindrom nyeri kronik menggambarkan sindrom diagnosis nyeri kronik yang berdampak keluhan lainnya pada respon klien, keluhan tersebut biasanya diagnosis gangguan pola tidur, isolasi sosial, kelelahan, atau gangguan mobilitas fisik. Kategori diagnosis sindrom dapat berupa risiko atau masalah. Contoh: 1) Sindrom kelelahan lansia, 2) Sindrom tidak berguna, 3) Sindrom post trauma, 4) Sindrom kekerasan. 


\section{Keuntungan diagnosa keperawatan}

1. Memfasilitasi komunikasi diantara perawat

2. Perbaikan kualitas asuhan keperawatan

3. Fokus pada pemenuhan tujuan perawatan kesehatan klien

4. Pengembangan keterampilan intelektual dan teknnis tenaga perawat

5. Penetapan tujuan yang tepat

6. Pemilihan prioritas yang tepat

7. Pemilihan intervensi yang tepat

8. Penetapan kriteria hasil yang tepat

9. Asuhan keperawatan bermutu dan dapat dipertanggungjawabkan secara ilmiah

4. Unsur-unsur yang terdapat dalam diagnosis keperawatan

1. pernyataan yang singkat, tegas, jelas tentang keadaan kesehatan pasien/klien

2. pasien/klien meliputi individu, keluarga dan masyarakat baik yang sakit maupun yang sehat

3. masalah kesehatan yang dihadapi yaitu:

a. ketidaktahuan tentang bagaimana mengatasi kebutuhan hidupnya sehari-hari

4. berhubungan dengan kesehatannya

a. ketidakmampuan/keengganan pasien untuk mengatasi masalah kebutuhan

5. hidupnya sehari berhubungan dengan kesehatannya

a. ketidakmampuan pasien atau klien memenuhi kebutuhan hidupnya sehari-hari

6. berhubungan dengan kesehatan

7. d.berhubungan dengan masalah kesehatan yang dihadapimya, baik etiologi atau

8. gejala yang dirasakan pasien

\section{PENUTUP}

Diagnosa keperawatan adalah suatu bagian integral dari proses keperawatan. Diagnosa Keperawatan merupakan keputusan klinik tentang respon individu, keluarga dan masyarakat tentang masalah kesehatan aktual atau potensial, dimana berdasarkan pendidikan dan pengalamannya, perawat secara akuntabilitas dapat mengidentifikasi dan memberikan intervensi secara pasti untuk menjaga, menurunkan, membatasi, mencegah dan merubah status kesehatan klien (Yeni, 2008). Langkah-langkah dalam perumusan diagnosa keperawatan adalah: Pengelompokan Data dan Analisa data, mengidentifikasi masalah klien, menvalidasi diagnosis keperawatan, menyusun diagnosis keperawatan sesuai dengan prioritasnya. 


\section{DAFTAR PUSTAKA}

Abdurrouf,M. , Kasim,M. (2016). PENINGKATAN KUALITAS PELAYANAN DAN PENDOKUMENTASIAN ASUHAN KEPERAWATAN DENGAN METODE TIM. NurseLine Journal, 1(1), 62-72

Apriyani,H. (2015). IDENTIFIKASI DIAGNOSIS KEPERAWATAN PADA PASIEN DI RUANG PARU SEBUAH RUMAH SAKIT . Jurnal Keperawatan, 11(1), 107-111

Dermawan, D. (2012). Proses Keperawatan Penerapan Konsep dan Kerangka Kerja. Yogyakarta: Gosyen Publishing.

Dinarti, \& Mulyanti, Y. (2017). Dokumentasi Keperawatan, Jaksel: Pusdik SDM Kesehatan

Effendi,F. (2008). Pendidikan dalam Keperawatan: Salemba Medika

Hidayah, N. (2014). Manajemen Model Asuhan Keperawatan Profesional (MAKP) Tim Dalam Peningkatan Kepuasan Pasien di Rumah Sakit. Jurnal Kesehatan, 7, 410-426.

Kholifah,S.N. (2016). Keperawatan Gerontik, Jaksel: Pusdik SDM Kesehatan

Rachmania, D. (2016). Pengembangan Instrument Diagnosis \& Intervensi Keperawatan Berbasis Standardized Nursing Language (NANDA-I, NOC, NIC). Jurnal Ners. 11(2)

Supratti.,\& Ashriady. (2016). PENDOKUMENTASIAN STANDAR ASUHAN KEPERAWATAN DI RUMAH SAKIT UMUM DAERAH MAMUJU, INDONESIA . Jurnal Kesehatan Manarang, 2(1), 44-51

Simamora, R. H., Bukit, E., Purba, J. M., \& Siahaan, J. (2017). Penguatan kinerja perawat dalam pemberian asuhan keperawatan melalui pelatihan ronde keperawatan di rumah sakit royal prima medan. Jurnal pengabdian kepada masyarakat, 23(2), 300-304.

Simamora, R. H. (2019). Socialization of Information Technology Utilization and Knowledge of Information System Effectiveness at Hospital Nurses in Medan, North Sumatra. Editorial Preface From the Desk of Managing Editor..., 10(9).

Yeni,F. (2014). Pengaruh Pelatihan Proses Keperawatan terhadap Dokumentasi Asuhan Keperawatan di Puskesmas Kabupaten Agam Propinsi Sumatera Barat . NERS JURNAL KEPERAWATAN,10(1),21-27 